\title{
TANGGUNG GUGAT NOTARIS DALAM PELAKSANAAN \\ PENDAFTARAN WASIAT SECARA ONLINE
}

\author{
Fanny Levia \\ Erni Agustin
}

\author{
Fakultas Hukum Universitas Airlangga \\ Kampus B, Jl. Dharmawangsa Dalam Selatan Surabaya \\ Email: fanny.levia@ymail.com, erni@fh.unair.ac.id
}

\begin{abstract}
Testament is the last will of a testator toward his wealth that will be executed after death. Each type and form of the will can be made either in an authentic deed before a public notary or privately made deed. The duty and responsibility of notary is to save and send a list of wills that have been made to the Property and Heritage Agency (BHP) and Central Register of Wills (DWP). In order to implemet the efficiency of the registration system, on March 28, 2014, the Ministry of Justice and Human Rights of the Republic of Indonesia (hereinafter referred to as Kemenkumham) has launched the online system for wills registration by the Notary. But in practice, there are still many who have not registered Notarial wills online to Kemenkumham. From this condition the issue is regarding the legal effect of the deed not registered online and the liability of notaries who do not register the will online. This paper is a normative legal research using statute, conceptual and historical approach. The study concluded that the status of a will that is not registered online at Kemenkumham is still as authentic documents, but it does not meet the principle of publicity that may result in the lack of knowledge of the heirs or the third parties. If there are losses, then heirs may sue the notary on the basis of onrechtmatigedaad where the notary did not meet its legal obligations.
\end{abstract}

Key words: online registration, testament, liability, notary

\begin{abstract}
Abstrak
Wasiat merupakan kehendak terakhir dari seorang pewaris terhadap harta kekayaan miliknya yang harus dilaksanakan setelah ia meninggal dunia. Notaris bertugas dan berkewajiban untuk menyimpan dan mengirim daftar wasiat yang telah dibuatnya ke Balai Harta Peninggalan (BHP) dan Daftar Pusat Wasiat (DWP). Dalam rangka untuk mewujudkan efisiensi dari sistem pendaftaran tersebut, pada tanggal 28 Maret 2014, Kementerian Hukum dan HAM Republik Indonesia (selanjutnya disebut Kemenkum HAM RI) melakukan launching sistem pendaftaran wasiat secara online oleh Notaris. Namun pada prakteknya masih banyak Notaris yang belum mendaftarkan wasiat secara online ke Kemenkum HAM RI. Dari hal tersebut muncul isu hukum mengenai akibat hukum dari akta wasiat yang tidak didaftarkan secara online dan mengenai tanggung gugat notaris yang tidak mendaftarkan wasiat secara online. Penelitian ini adalah penelitian hukum normatif, menggunakan pendekatan undang-undang (statute approach), pendekatan konseptual (conceptual approach) dan pendekatan historis (historical approach). Hasil penelitian menyimpulkan bahwa kedudukan akta wasiat yang tidak didaftarkan secara online pada Kemenkumham adalah tetap sebagai akta otentik, namun tidak memenuhi asas
\end{abstract}


publisitas yang dapat membuat pihak ketiga atau ahli waris dianggap tidak mengetahui adanya suatu wasiat yang ditujukan bagi mereka. Apabila terdapat kerugian yang ditimbulkan, maka ahli waris dapat menggugat notaris atas dasar perbuatan melanggar hukum dimana notaris yang bersangkutan tidak memenuhi kewajiban hukumnya.

Kata kunci: pendaftaran online, wasiat, tanggung gugat, notaris

\section{Latar Belakang}

Setiap orang tentu akan berusaha memenuhi kebutuhannya sehari-hari agar tetap dapat bertahan hidup. Namun, tidak semua orang akan menemui kemudahan dalam berusaha. Bagi mereka yang memiliki kemampuan lebih, untuk mengumpulkan atau memiliki harta benda tentu bukanlah sesuatu yang sulit. Harta yang telah dikumpulkan semasa hidup, tentunya tidak akan dibawa mati. Pada umumnya, harta dari seseorang yang telah meninggal dunia akan jatuh kepada keluarga dan orang terdekatnya atau yang lebih dikenal juga sebagai ahli waris yang mana hal ini diatur dalam hukum waris. Menurut Klaassen-Eggens, hukum waris adalah hukum yang mengatur tentang perpindahan harta kekayaan dan terjadinya hubungan-hubungan hukum sebagai akibat kematian seseorang. ${ }^{1}$ Hal ini sejalan dengan ketentuan dalam Pasal 830 Burgerlijk Wetboek (selanjutnya disebut BW) yang menyatakan bahwa pewarisan hanya berlangsung karena kematian dimana ketentuan ini selanjutnya diatur dalam ketentuan Pasal 874 BW yang menegaskan bahwa segala harta peninggalan seorang yang meninggal dunia, adalah kepunyaan sekalian ahli warisnya menurut undang-undang, sekadar terhadap itu dengan surat wasiat tidak telah diambilnya sesuatu ketetapan yang sah. Dalam BW ada dua cara untuk mendapatkan harta warisan, yaitu:

a. Sebagai ahli waris menurut ketentuan undang-undang ( $a b$ intestate) ;

b. Karena seseorang ditunjuk dalam surat wasiat (testamentair). ${ }^{2}$

Orang yang memiliki harta terkadang berkeinginan agar hartanya kelak jika ia meninggal dapat dimanfaatkan sesuai kebutuhan ahli waris. Untuk itu hukum memperbolehkan si pemilik harta memberikan hartanya menurut keinginannya sendiri dimana hal ini menyimpang dari ketentuan hukum waris, ini adalah wajar sebab pada prinsipnya seorang pemilik harta bebas memperlakukan hartanya sesuai keinginannya. ${ }^{3}$ Tetapi, dalam kenyataannya tidak sedikit terjadi konflik dalam hal pembagian harta benda yang ditinggalkan atau yang disebut juga harta peninggalan oleh si pemilik benda.

Berkaitan dengan hal tersebut, pemilik benda atau dalam hal ini disebut juga pewaris, membuat sebuah wasiat yang berkaitan dengan harta peninggalannya. Wasiat ini

1 R. Soetojo Prawirohamidjojo, Hukum Waris Kodifikasi, (Surabaya: Airlangga University Press, 2000), hlm. 1.

2 Zainuddin Ali, Pelaksanaan Hukum Waris di Indonesia, (Jakarta: Sinar Grafika, 2010), hlm. 82.

3 Oemarsalim, Dasar-Dasar Hukum Waris di Indonesia, (Jakarta: Rineka Cipta, 2012), hlm. 82. 
dibuat semasa si pewaris masih hidup dan baru akan berlaku sejak pewaris meninggal dunia. Yang dimaksud dengan wasiat atau testament itu sendiri menurut Pasal 875 BW ialah suatu akta yang memuat pernyataan seseorang tentang apa yang dikehendakinya akan terjadi setelah ia meninggal dunia, dan yang olehnya dapat dicabut kembali lagi.

Pewarisan dengan akta wasiat (testament acte) sudah dikenal sejak jaman Romawi. Bahkan pewarisan dengan menggunakan akta wasiat (testament acte) menjadi suatu hal yang utama. Pada jaman Kaisar Justinianus, hukum Romawi mengenal dua bentuk testament, yaitu lisan dan tertulis. Pada waktu membuat testament, baik tertulis maupun lisan, harus hadir tujuh orang saksi. Pada testament yang tertulis, para saksi harus ikut menandatangani surat yang memuat kehendak terakhir dari si pewaris itu. Sedangkan pada testament yang lisan, para saksi cukup mendengarkan saja apa yang diterangkan oleh si pewaris. ${ }^{4}$

Wasiat sendiri terdiri dari jenis dan bentuk yang berbagai macam. Dilihat dari isinya, wasiat terbagi menjadi dua, yaitu wasiat yang berisi erfstelling atau wasiat pengangkatan waris dan wasiat yang berisi hibah (hibah wasiat) atau legaat. Sedangkan dari bentuknya, wasiat terbagi atas wasiat yang harus ditulis sendiri (Olographis Testament), wasiat umum (Openbaar Testament), wasiat rahasia atau testament tertutup (Geheim), pembuatan testament di luar negeri dan pembuatan testament dalam keadaan luar biasa. ${ }^{5}$

Setiap jenis dan bentuk wasiat di atas dapat dibuat baik dalam akta otentik di hadapan notaris maupun akta bawah tangan. Notaris bertugas dan berkewajiban untuk menyimpan dan mengirim daftar wasiat yang telah dibuatnya ke Balai Harta Peninggalan (BHP) dan Daftar Pusat Wasiat (DWP). Di dalam Rancangan Undang-Undang Balai Harta Peninggalan pada Pasal 3 huruf $\mathrm{b}$ disebutkan bahwa Balai Harta Peninggalan mempunyai tugas melaksanakan penyelesaian pembukaan dan pendaftaran surat wasiat sesuai dengan peraturan perundang-undangan.

Seiring perkembangan dan perubahan sistem Hukum di Indonesia, pada tahun 1987 semua perwakilan Balai Harta Peninggalan (BHP) di seluruh Indonesia dihapuskan sesuai Keputusan Menteri Kehakiman R.I. Nomor M.06-PR.07.01 Tahun 1987. Saat ini hanya ada 5 (lima) Balai Harta Peninggalan di Indonesia, yaitu di Jakarta, Semarang, Surabaya, Medan dan Makassar dan masingmasing meliputi wilayah kerja daerah tingkat I dan tingkat II. Untuk Balai Harta Peninggalan (BHP) Jakarta, mempunyai 8 (delapan) wilayah kerja meliputi DKI Jakarta, Jawa Barat, Banten, Lampung, Sumatera Selatan, Bangka Belitung, Jambi dan Kalimantan Barat. Sesuai Peraturan Menteri Hukum dan Hak Asasi Manusia RI tanggal 1 Maret 2005

4 Mireille Titisari Miarti Prastuti, "Peran dan Tanggung Jawab Notaris Atas Akta Wasiat (Testament Acte) yang dibuat di hadapannya", Tesis Program Magister Kenotariatan, (Semarang: UNDIP, 2006), http://eprints.undip. ac.id/15710/1/M. Titisari Miarti Prastuti.pdf., diakses 10 Desember 2016.

5 Maman Suparman, Hukum Waris Perdata, (Jakarta: Sinar Grafika, 2015), hlm. 107. 
Nomor M-01.PR.07.10 tahun 2005 tentang Organisasi dan Tata Kerja Kantor Wilayah Departemen Hukum dan Hak Asasi Manusia Republik Indonesia, BHP merupakan Unit Pelaksana Teknis yang berada di Lingkungan Kantor Wilayah Kementerian Hukum dan Hak Asasi Manusia dibawah Divisi Pelayanan Hukum dan HAM, namun secara teknis bertanggung jawab langsung pada Direktorat Jenderal Administrasi Hukum Umum melalui Direktorat Perdata.

Dalam rangka untuk mewujudkan efisiensi dari sistem pendaftaran tersebut, pada tanggal 28 Maret 2014, Kementerian Hukum dan HAM Republik Indonesia (selanjutnya disebut Kemenkum HAM RI) mengeluarkan sistem pendaftaran wasiat secara online oleh Notaris. Selanjutnya, telah diterbitkan pula Peraturan Menteri Hukum dan HAM Nomor 60 Tahun 2016 tentang Tata Cara Pelaporan Wasiat dan Permohonan Penerbitan Surat Keterangan Wasiat Elektronik (selanjutnya disebut Permenkumham No. 60/2016) sebagai landasan untuk pelaporan wasiat yang dilakukan secara online. Namun, pada prakteknya masih banyak Notaris yang belum mendaftarkan wasiat secara online ke Kemenkum HAM RI. Sedangkan Pasal 16 ayat (1) huruf j Undang-Undang Nomor 2 Tahun 2014 Tentang Perubahan Atas UndangUndang Nomor 30 Tahun 2004 Tentang Jabatan Notaris (selanjutnya disebut UUJN) menyatakan bahwa dalam menjalankan jabatannya, Notaris wajib mengirimkan daftar Akta sebagaimana dimaksud dalam huruf I atau daftar nihil daftar wasiat pada kementerian yang menyelenggarakan urusan pemerintahan di bidang hukum dalam waktu 5 (lima) hari pada minggu pertama setiap bulan berikutnya. Namun, di dalam UndangUndang Jabatan Notaris yang baru ini tidak menyebutkan mengenai denda dari tiap-tiap keterlambatan, baik keterlambatan tentang daftar akta wasiat kepada Kemenkum HAM RI dan keterlambatan tentang pengiriman pencatatan repertorium.

Pasal 943 BW mengatur bahwa tiap-tiap Notaris yang menyimpan surat-surat wasiat di antara surat-surat aslinya, dalam bentuk apa pun juga harus, setelah si yang mewariskan meninggal dunia, memberitahukannya kepada semua yang berkepentingan. Berdasarkan ketentuan tersebut maka dapat disimpulkan bahwa Notaris memiliki fungsi penting dalam pembuatan akta wasiat dari proses awal hingga akhir sehingga akta wasiat tersebut memiliki kekuatan hukum yang mengikat.

Berdasarkan uraian latar belakang di atas, maka dalam tulisan ini mengkaji permasalahan yang berkaitan dengan Notaris khususnya mengenai “Tanggung Gugat Notaris Dalam Pelaksanaan Pendaftaran Wasiat Secara Online". Rumusan masalah yang dikaji dalam artikel ini adalah sebagai berikut:

a. Akibat hukum dari wasiat yang tidak didaftarkan secara online di Kementerian Hukum dan HAM RI.

b. Tanggung gugat notaris yang tidak mendaftarkan wasiat secara online pada Kementerian Hukum dan HAM RI. 
Metode penelitian yang akan digunakan dalam penelitian ini adalah metode penelitian hukum normatif, dengan menggunakan beberapa pendekatan masalah, antara lain dengan pendekatan undang-undang (statute approach) yang dilakukan dengan menelaah semua undang-undang dan regulasi yang berkaitan dengan isu hukum yang sedang ditangani, pendekatan konseptual (conceptual approach) yang mana pendekatan ini mengacu pada definisi, konsep serta pendapat/ argumentasi para ahli hukum, selain itu digunakan juga pendekatan historis (historical approach) yang dilakukan dalam kerangka pelacakan sejarah lembaga hukum dari waktu ke waktu dimana peneliti juga dapat memahami perubahan dan perkembangan filosofi yang melandasi aturan hukum tersebut. Berkaitan dengan masalah mendasar dari artikel ini adanya norma yang kabur mengenai akibat hukum dari wasiat yang tidak didaftarkan secara online di Kementerian Hukum dan HAM RI dan tanggung gugat notaris yang terlambat mendaftarkan wasiat secara online pada Kementerian Hukum dan HAM RI. ${ }^{6}$

\section{Pembahasan}

A. Akibat Hukum dari Wasiat yang Tidak Didaftarkan secara Online di Kementerian Hukum Dan Hak Asasi Manusia Republik Indonesia

\section{Jenis-jenis wasiat}

Wasiat (testament), yaitu pernyataan seseorang mengenai apa yang dikehendaki setelah meninggal dunia. Pada asasnya suatu pernyataan kemauan adalah datang dari satu pihak saja (eenzigdig) dan setiap waktu dapat ditarik kembali oleh yang membuatnya. Penarikan kembali itu (herrolpen) boleh secara tegas (uitdrukkelijk) atau secara diamdiam (stilzwijgend). ${ }^{7}$

Wasiat menurut Pasal 875 BW adalah suatu akta yang berisi pernyataan seseorang tentang apa yang akan terjadi setelah ia meninggal dunia dan olehnya dapat ditarik kembali. Pernyataan dimaksud berkaitan dengan harta peninggalan milik seseorang yang berdasarkan Pasal 874 BW bahwa segala harta peninggalan seseorang yang meninggal dunia pada prinsipnya adalah kepunyaan sekalian ahli warisnya. Menurut undangundang, terhadap hal itu dengan surat wasiat telah diambil suatu ketetapan yang sah. ${ }^{8}$

Suatu wasiat (testament) harus dalam bentuk tertulis yang dibuat dengan akta di bawah tangan maupun dengan akta otentik. Akta ini berisikan pernyataan kehendak sebagai tindakan hukum sepihak, yang berarti pernyataan itu datangnya dari satu pihak saja. Dengan kata lain, testament merupakan pernyataan mengenai suatu hal sesudah ia meninggal dunia. Jadi, testament

6 Peter Mahmud Marzuki, Penelitian Hukum, (Jakarta: Kencana, 2005), hlm. 133.

7 R. Subekti, Pokok-Pokok Hukum Perdat, Cetakan XXXII, (Jakarta: Intermasa, 2005), hlm. 107.

8 Maman Suparman, op.cit., hlm. 105. 
baru mempunyai akibat sesudah si pewaris meninggal dunia. ${ }^{9}$

Ketentuan lain dalam pembuatan surat wasiat ini adalah bahwa pembuat wasiat harus menyatakan kehendaknya yang berupa amanat terakhir ini secara lisan di hadapan notaris dan saksi-saksi. Salah satu ciri dan sifat yang terpenting dan khas dalam setiap surat wasiat, yaitu surat wasiat selalu dapat ditarik kembali oleh si pembuatnya. Hal ini disebabkan tindakan membuat surat wasiat adalah merupakan perbuatan hukum yang sifatnya sangat pribadi. $^{10}$ Pasal 930 BW melarang bahwa surat wasiat dibuat oleh dua orang atau lebih. Ketentuan ini ada hubungannya dengan sifat khusus dan penting suatu surat wasiat, yaitu bahwa surat wasiat selalu dapat dicabut. Apabila undang-undang mengijinkan beberapa orang membuat wasiat dalam surat wasiat, maka dalam hal pencabutan dapat timbul kesulitan. Alasan utama larangan tersebut adalah kerahasiaan isi wasiat. ${ }^{11}$

Pasal 931 BW menentukan bahwa surat wasiat dapat dibuat dengan tiga macam cara yaitu dengan suatu akta olografis atau ditulis tangan; dengan akta umum; atau dengan penentuan rahasia atau tertutup. Pembagian testament menurut bentuknya dapat dilakukan dalam dua macam, yaitu dengan akta umum dan tidak dengan akta umum, yang dibedakan lagi dalam olografis dan rahasia. ${ }^{12}$

Dilihat dari jenisnya, wasiat dapat dibedakan menjadi 2 yaitu:

a. Wasiat yang berisi erfstelling atau wasiat pengangkatan waris.

Pasal 954 BW menyatakan bahwa yang dimaksud dengan wasiat pengangkatan waris adalah wasiat dengan mana orang yang mewasiatkan, memberikan kepada orang atau lebih dari seorang, seluruh atau sebagian (setengah atau sepertiga dari harta kekayaannya, kalau ia meninggal dunia). Mereka yang mendapat harta kekayaan menurut pasal itu disebut waris di bawah tetelum.

b. Di dalam Pasal 957 BW mengatur tentang wasiat yang berisi hibah (hibah wasiat) atau legaat. Ketetntuan ini menyatakan bahwa hibah wasiat adalah suatu penetapan wasiat yang khusus, dengan mana si yang mewariskan kepada seorang atau lebih memberikan beberapa barang-barangnya dari suatu jenis tertentu, seperti misalnya segala barangbarang bergerak atau tak bergerak, atau memberikan hak pakai hasil atas seluruh atau sebagian harta peninggalannya. ${ }^{13}$

Sedangkan menurut Pasal 931 BW ada tiga bentuk surat wasiat, yaitu wasiat yang harus ditulis sendiri (olographis testament),

9 Ibid.

10 Eman Suparman, op.cit., hlm. 98.

11 Tan Thong Kie, Studi Notariat dan Serba-Serbi Praktek Notaris, (Jakarta: Ichtiar Baru Van Hoeve, 2007), hlm. 267.

12 R. Soetojo Prawirohamidjojo, op.cit., hlm.176.

13 Maman Suparman, op.cit., hlm. 107. 
wasiat umum (openbaar testament), dan wasiat rahasia.

Mengenai wasiat yang harus ditulis sendiri (Olographis Testament), Pasal 932 BW memuat beberapa ketentuan sebagai berikut:

1. Wasiat harus ditulis sendiri dan ditandatangani oleh pewaris.

2. Harus diserahkan atau disimpan sendiri oleh notaris. Hal-hal atau peristiwa yang dibuatkan suatu akta disebut akta penyimpanan notaris (akta van depot) dan akta ini harus ditandatangani oleh :
a. Yang membuat wasiat;
b. Notaris;
c. Dua orang saksi.

3. Jika wasiat disampaikan secara tertutup (dalam sampul tertutup), maka hal tersebut harus dibuat di atas kertas tersendiri, dan di atas sampul itu harus diberi catatan bahwa sampul itu berisi surat wasiat dan catatannya harus ditandatangani. Apabila wasiat diserahkan dalam keadaan terbuka, maka akta dapat ditulis di bawah surat wasiat itu sendiri. ${ }^{14}$

Menurut Code, untuk berlakunya testament olographis, tidak ada syarat bahwa harus disimpan oleh notaris. Pewaris dapat menggunakan seluruh harta peninggalannya dengan surat yang ditulis, ditandatangani serta ditanggali dan disimpannya sendiri. ${ }^{15}$ Kekuatan pembuktian wasiat olographis ditentukan dalam Pasal 933 BW yang menentukan bahwa apabila surat wasiat tersebut setelah berada dalam penyimpanan notaris, kekuatannya sama dengan surat wasiat umum (openbaar testament). Dalam hal ini seluruhya dikerjakan oleh notaris. Wasiat olographis ini juga sewaktu-waktu dapat ditarik kembali oleh yang membuatnya, hal ini ditegaskan dalam Pasal 934 BW. Penarikan wasiat ini dapat dilakukan dengan cara yang bersangkutan datang kepada notaris dimana wasiat itu disimpan. Selanjutnya ia menyatakan kehendaknya untuk meminta kembali wasiat yang pernah disimpan tersebut dan dibuatkan akta tersendiri untuk disimpan oleh notaris.

Pelaksanaan wasiat olographis dan wasiat pada umumnya sama, yakni setelah orang yang membuat wasiat itu meninggal dunia. Jika wasiat itu dalam keadaan tertutup, maka notaris yang menyimpannya membawa wasiat itu ke Balai Harta Peninggalan (selanjutnya disebut BHP). Oleh BHP wasiat itu dibuka karena notaris tersebut tidak berwenang membukanya. Pembukaan wasiat olographis harus dibuatkan aktanya yang dinamakan proses verbal akta dan harus disebutkan pula keadaan isi wasiat tersebut. Setelah wasiat dibuka dan dibuatkan aktanya, BHP menyerahkan kembali pelaksanaan wasiat tersebut kepada notaris yang menyimpannya. ${ }^{16}$ Selanjutnya adalah wasiat umum atau openbaartestament yaitu yang dibuat oleh

14 Ali Afandi, Hukum Waris, Hukum Keluarga, Hukum Pembuktian, Cetakan Ke-Empat, (Jakarta: Rineka Cipta, 2000), hlm. 17.

15 R. Soetojo Prawirohamidjojo, loc.cit. 
notaris. Dalam hal ini, pihak yang ingin membuat wasiat datang sendiri menghadap notaris dan menyatakan kehendaknya. Selanjutnya notaris membuatkan wasiat yang dikehendaki oleh orang yang menghadap tersebut. Wasiat umum diatur dalam Pasal 938 dan 939 BW, yaitu sebagai berikut:

1. Harus dibuat dihadapan notaris dan dihadiri oleh dua orang saksi atau empat orang saksi khusus untuk pembuatan akta wasiat di bawah tangan.

2. Pewaris menerangkan kepada notaris apa yang dikehendaki.

3. Dalam inti atau pokok ketentuan tersebut, notaris menulis kalimat yang jelas mengenai apa yang diterangkan oleh pewaris. Dalam hal ini ada perbedaan pendapat tentang wasiat umum. Kedua pendapat itu yaitu pertama, wasiat dapat dilakukan dengan lisan, alasannya adalah:

a. Dihadiri oleh saksi yang harus mendengarkan keterangan itu;

b. Testament umum disebut juga testament lisan;

c. Kalimat yang ditulis hanya pokoknya saja. Kedua, wasiat dapat dilakukan secara tertulis, misalnya si pewaris dalam keadaan sakit, sehingga ia tidak bisa berbicara dan memberi keterangan secara tertulis. Notaris lalu membaca tulisan itu dan menanyakan apakah betul demikian kehendaknya.

Jika pewaris mengangguk maka keterangan itu dianggap betul. Pendapat kedua ini juga dianut oleh Wirjono Prodjodikoro.

4. Jika keterangan pewaris dinyatakan tanpa hadirnya para saksi dan dari wasiat telah dibuat oleh notaris, maka pewaris harus menerangkan sekali lagi di hadapan para saksi tentang maksud dibuatnya surat wasiat. Kemudian konsep itu dibaca lagi dengan hadirnya para saksi. Apabila sudah betul, maka testament tersebut ditandatangani pewaris, saksi dan notaris.

5. Apabila pewaris tidak hadir, hal ini disebutkan dalam wasiat dan penyebab ketidakhadiran pewaris.

6. Surat wasiat juga menyebutkan segala kelengkapan acara telah dipenuhi. ${ }^{17}$

Hukum waris barat berlaku bagi orangorang keturunan timur asing yang bukan Tionghoa. Dalam hal ini berdasarkan Stbl. 1924-556 Pasal 4, dimungkinkan membuat testament, tetapi hanya dalam bentuk testament umum saja. ${ }^{18}$

Kemudian yang ketiga adalah Wasiat Rahasia atau Testament Tertutup (Geheim). Testament rahasia diatur dalam Pasal 940 dan 941 BW. Pasal 940 BW menyebutkan bahwa wasiat rahasia adalah suatu wasiat yang dibuat sendiri oleh orang yang akan meninggalkan wasiat tetapi tidak harus ditulis dengan tangan sendiri. Testament ini harus selalu dalam keadaan tertutup dan disegel. Penyerahan testament ini kepada notaris, harus dihadiri 
oleh empat orang saksi. ${ }^{19}$ Cara membuat surat wasiat ini adalah sebagai berikut :

1. Wasiat harus ditulis sendiri oleh pewaris atau orang lain atas namanya dan pewaris menandatanganinya sendiri.

2. Kertas atau sampul yang memuat tulisan ini harus ditutup dan disegel.

3. Kertas atau sampul harus diberikan kepada notaris yang dihadiri empat orang saksi. Pewaris harus menerangkan bahwa kertas itu berisi wasiatnya yang ia tulis sendiri (atau ditulis orang lain atas namanya) dan diberi tanda tangan.

4. Keterangan ini oleh notaris harus ditulis dalam akta yang dinamakan akta superscriptie (akta pengalamatan). Akta itu harus ditulis di atas kertas atau sampul yang diberi alamat dan ditandatangani oleh notaris dan empat orang saksi tersebut. ${ }^{20}$

Adapun menurut Pasal 942 BW bahwa orang yang meninggalkan testament rahasia meninggal dunia maka notaris harus menyampaikan testament itu kepada BHP untuk selanjutya membuka testament tersebut. Dalam penerimaan dan pembukaan testament itu, BHP harus membuat proses verbal, kemudian testament tersebut harus dikembalikan pada notaris, dimana wasiat itu disimpan. ${ }^{21}$ Semua jenis testament memuat ketentuan yang diatur dalam Pasal
930 BW, yaitu testament tidak dibolehkan menguntungkan satu sama lain dan kepentingan orang ketiga.

Dalam hal pembuatan testament dilakukan di luar negeri diatur dalam Pasal 954 BW yang menyatakan bahwa seorang Warga Negara Indonesia yang berada di negeri asing tidak diperbolehkan membuat surat wasiat, melainkan dengan akta otentik dan dengan mengindahkan tertib cara yang lazim, di negeri di mana surat wasiat itu dibuatnya. Sementara itu, ia berhak dengan surat bawah tangan membuat sesuatu ketetapan atas dasar dan cara seperti diatur dalam Pasal 935 BW. Jadi dimana pun tempat di luar negeri, asalkan terdapat konsul Republik Indonesia, maka konsul tersebut bisa melaksanakan perbuatan yang biasa dilakukan oleh seorang notaris di Indonesia. $^{22}$

\section{Kecakapan membuat wasiat dan syarat-syarat wasiat}

Seseorang yang akan membuat wasiat harus sudah mencapai usia 18 tahun atau sudah dewasa. Hal tersebut diatur dalam Pasal 897 BW yang menyatakan bahwa anak-anak di bawah umur yang belum mencapai umur delapan belas tahun, tidak diperbolehkan membuat surat wasiat. Di samping itu, ketentuan lain yang mengatur sahnya suatu testament yaitu pasal-pasal sebagai berikut

19 Benyamin Asri \& Thabrani Asri, Dasar-Dasar Hukum Waris Barat (Suatu Pembahasan Teoritis dan Praktik), (Bandung: Tarsito, 1988), hlm. 46.

20 Ali Afandi, op.cit., hlm. 20.

21 Ibid.

22 Oemarsalim, op.cit., hlm. 107. 
atau yang dapat disebut juga sebagai syarat formil dari suatu wasiat.

Yang pertama adalah Pasal 888 BW yang memuat ketentuan bahwa dalam segala surat wasiat, tiap-tiap syarat yang tak dapat dimengerti, atau tak mungkin dilaksanakan, atau yang bertentangan dengan kesusilaan yang baik harus dianggap sebagai tak tertulis. Pasal ini menekankan bila dalam pembuatan suatu wasiat harus tetap memperhatikan asas-asas kesusilaan dan kesopanan dalam masyarakat. Sedangkan Pasal 890 BW menyatakan jika di dalam testament disebut sebab yang palsu, dan isi dari testament itu menunjukkan bahwa pewaris tidak akan membuat ketentuan itu jika ia tahu akan kepalsuannya maka testament tidaklah sah. Melalui ketentuan ini dapat dilihat bahwa testament yang dibuat tidak boleh berisikan suatu keterangan yang palsu dan dapat berakibat testament itu dinyatakan tidak sah apabila pemberi wasiat mengetahui adanya kepalsuan di dalam testament tersebut.

Suatu wasiat tidak boleh dibuat oleh lebih dari satu orang dan wasiat tersebut tidak boleh untuk menguntungkan suatu pihak. Ketentuan tersebut didasarkan pada Pasal 930 BW yang menyatakan bahwa dua orang atau lebih tidak diperbolehkan menyatakan wasiat mereka, baik untuk menguntungkan pihak ketiga, maupun untuk keuntungan timbal balik.

Dalam pembuatan wasiat tidak boleh terdapat unsur paksaan, tipuan atau muslihat sebagaimana diatur dalam Pasal 893 BW yang mana wasiat tersebut akan menjadi batal. Di dalam hukum waris, di samping larangan secara umum terdapat larangan yang tidak boleh dimuat dalam testament, yakni larangan membuat suatu ketentuan yang menyebabkan legitieme portie (bagian mutlak para ahli waris) menjadi kurang dari semestinya.

Sedangkan syarat materil yang harus ada dalam suatu wasiat diatur dalam Pasal 879, 885, 904, 905, 906, 907, 911, 912 BW. Pasal 879 BW yang mengatur tentang fideicommis, yaitu pengangkatan waris atau pemberian hibah dengan lompat tangan, hal ini dilarang (fideicommisatau disebut juga dengan wasiat bersyarat).Pasal 885 BW menyatakan apabila kata-kata dalam wasiat cukup jelas, maka dalam pelaksanaannya tidak boleh menyimpang dari isi dan maksud wasiat tersebut. Ada pula larangan bagi anak yang belum dewasa atau telah berumur 18 tahun untuk menghibah-wasiatkan sesuatu guna kepentingan wali atau bekas wali, melainkan setelah wali tersebut mengadakan perhitungan tanggung jawabnya atas perwaliannya, kecuali wasiat untuk kepentingan keluarga sedarah dalam garis lurus ke atas, yang masih menjadi wali atau bekas walinya yang diatur dalam Pasal 904 BW.

Pasal 905 BW mengatur larangan bagi anak yang belum dewasa menghibah-mewasiatkan sesuatu kepada pengajar mereka, kepada guru yang tinggal serumah dengan mereka, kecuali guna membalas jasa dengan memperhatikan jasa-jasa yang telah diperbuat dan terhadap harta kekayaan si penghibah. Dan Pasal 906 BW mengatur larangan untuk menghibahmewasiatkan sesuatu kepada tabib atau dokter 
yang telah melayani seseorang sewaktu ia menderita sakit sampai akhir hidupnya, kecuali:

a. Segala ketetapan dalam bentuk hibah wasiat, guna membalas jasa-jasa yang telah diberikan;

b. Segala ketetapan untuk kepentingan suami atau istri dari orang yang mewariskan;

c. Segala ketetapan untuk keuntungan para keluarga sedarah sampai derajat keempat seandainya orang yang mewariskan tidak meninggalkan ahli waris dalam garis lurus.

Pasal 907 BW yang mengatur tentang larangan bagi notaris yang dengan perantaraannya telah dibuat akta wasiat, dan para saksi yang telah menyaksikan pembuatan akta wasiat, tidak diperbolehkan menikmati, mengambil keuntungan sedikit pun dari ketetapan wasiat itu. Pasal 911 BW menyatakan bahwa suatu ketetapan waris yang diambil guna keuntungan seorang yang tidak cakap untuk mewaris, adalah batal. Sekalipun ketetapan itu diambilnya bagi nama seorang perantara. Perantara di sini adalah bapak dan ibu, anak-anak serta keturunan dari anak-anak, dan istri atau suami orang tidak cakap itu. Jadi, wasiat dilarang kepada orang yang tidak cakap walaupun diberikan melalui perantara. Sedangkan Pasal 912 BW mengatur tentang larangan kepada orangorang tertentu untuk mengambil keuntungan dari surat wasiat, yaitu: a. Mereka yang telah dihukum karena membunuh orang yang mewariskan;

b. Mereka yang telah menggelapkan, membinasakan dan memalsukan surat wasiatnya;

c. Mereka yang dengan paksa atau kekerasan telah mencegah orang yang mewariskan untuk mengubah atau mencabut surat wasiat, sekalipun dilakukan oleh istri atau suami dan anak-anak mereka. ${ }^{23}$

\section{Fungsi notaris dalam pembuatan wasiat}

Wasiat dapat dibuat baik dalam akta otentik di hadapan notaris maupun akta bawah tangan. Untuk setiap wasiat yang dibuat di hadapan notaris, atas akta wasiat tersebut notaris bertugas dan berkewajiban untuk menyimpan dan mengirim daftar wasiat yang telah dibuatnya tersebut ke BHP dan Daftar Pusat Wasiat (selanjutnya disebut DPW).

Keberadaan BHP di Indonesia telah ada sejak kurang lebih 389 tahun lalu. Sejarah dan pembentukan BHP dimulai dengan masuknya bangsa Belanda ke Indonesia, yang pada mulanya mereka datang sebagai pedagang. Dalam dunia perdagangan di Indonesia mereka bersaing dengan pedagangpedagang asing lainnya, seperti Cina, Inggris, Portugis yang memiliki armada-armada besar. Untuk menghadapi persaingan tersebut, orang-orang Belanda kemudian pada tahun 1602 mendirikan suatu perkumpulan dagang yang diberi nama Vereenigde Oost Indische 
Companie yang disingkat dengan VOC yang oleh bangsa Indonesia dikenal Kompeni. ${ }^{24}$

Pendirian VOC ini mendapat restu dan pengesahan oleh Pemerintah Belanda serta diperbolehkan membentuk angkatan perang untuk berperang dan memerintah daerah yang ditaklukkan. Demikian VOC di samping berdagang juga mempunyai maksud lain yaitu melakukan penjajahan terhadap daerah-daerah yang ditaklukkan.Semakin lama kekuasaan VOC di Indonesia semakin luas, maka akhirnya timbul kebutuhan bagi para anggota khususnya dalam mengurus harta kekayaan yang ditinggalkan oleh mereka bagi kepentingan para ahli waris yang berada di Netherland, anak-anak yatim piatu dan sebagainya. Untuk menanggulangi kebutuhan itu akhirnya oleh Pemerintah Belanda dibentuk suatu lembaga yang diberi nama Wees-en Boedelkamer atau Weskamer (Balai Harta Peninggalan) yang pertama kali didirikan di Jakarta pada tanggal 1 Oktober 1624, sedangkan pendirian BHP di daerah lain sejalan dengan kemajuan territorial yang dikuasai VOC untuk memenuhi kebutuhan anggota VOC. ${ }^{25}$

BHP memiliki beberapa tugas yang bila dikategorikan terbagi dalam beberapa klasifikasi yang salah satu klasifikasinya ialah di bidang hak waris yaitu :
a. Membuat Surat Keterangan Hak Mewaris;
b. Mendaftar wasiat yang sudah terbuka;

c. Membuka wasiat tertutup;

d. Pemecahan dan pembagian waris (boedelscheiding).

Tugas BHP yang terkait dengan notaris adalah dalam hal membuka wasiat tertutup, baik berupa wasiat olografis yang tertutup sebagaimana dimaksud dalam Pasal 937 jo Pasal 942 BW maupun wasiat rahasia yang diatur dalam Pasal 940 jo Pasal 942 BW. BHP hanya membuat Berita Acara Pembukaan Wasiat Tertutup saja, tetapi terhadap isi wasiat tetap menjadi kewajiban notaris untuk pelaksanaannya lebih lanjut.Selain itu tugas lain BHP yang terkait dengan notaris adalah dalam hal pendaftaran wasiat yang sudah terbuka (ketika Pewaris meninggal dunia), yang dimaksud ialah pelaksanaannya harus didaftarkan terlebih dahulu ke BHP untuk memenuhi asas publisitas.

Sedangkan DPW merupakan salah satu seksi dari Subdirektorat Harta Peninggalan yang berada dibawah dan bertanggungjawab langsung kepada Direktorat Jenderal Administrasi Hukum Umum melalui Direktorat Perdata. Subdirektorat Harta Peninggalan mempunyai tugas melaksanakan penyiapan rancangan kebijakan, pembinaan teknis dan pengawasan atas pelaksanaan tugas BHP serta penanganan daftar wasiat dan pemberian surat keterangan wasiat serta pengelolaan arsip dan dokumen.

Seksi DPW mempunyai tugas melakukan penyusunan daftar wasiat (testament) yang

24 Nurhendro Putranto, Balai Harta Peninggalan Fungsi dan Tugas Pokoknya, (Surabaya: Balai Harta Peninggalan Surabaya, 2013), hlm. 1.

25 Ibid. 
dilaporkan oleh notaris baik testament terbuka, testament tertulis maupun testament tertutup atau rahasia, serta meneliti daftar formal daftar wasiat dan penyiapan bahan penyelesaian permohonan surat keterangan wasiat.

Pelaksanaan tugas BHP dalam hal pembukaan dan pendaftaran surat wasiat, berkaitan erat dengan tugas dan wewenang yang dimiliki oleh notaris yang diatur dalam UUJN. Pasal 875 BW menyatakan bahwa yang dinamakan dengan surat wasiat atau testament adalah suatu akta yang memuat pernyataan seorang tentang apa yang dikehendakinya akan terjadi setelah ia meninggal dunia, dan yang olehnya dapat dicabut kembali. Apabila seseorang telah membuat surat wasiat atau meminta kepada notaris untuk membuatkan surat wasiat, maka surat wasiat tersebut oleh notaris wajib untuk dilakukan pendaftaran kepada BHP dimana wilayah hukum dari notaris itu berada yang mana wasiat tersebut juga akan dilaporkan ke DPW untuk selanjutnya diberikan surat tembusan kepada BHP dan oleh BHP akan dimasukkan ke dalam buku register. Pendaftaran yang dimaksud dalam hal ini ialah pelaporan mengenai wasiat yang dibuat di hadapan notaris, yang mana pelaporan ini dilakukan secara manual. Dan pada saat pewaris telah meninggal dunia, ahli waris dapat mengajukan permohonan ke BHP untuk membuka surat wasiat yang tertutup atau rahasia dengan persyaratan sebagai berikut:

a. Surat permohonan;

b. Akta Kematian atau Surat Kematian;

c. Semua ahli waris harus hadir di BHP dan Notaris penyimpan wasiat;

d. Surat wasiat;

e. Identitas para pihak;

Surat Keterangan Wasiat dari Direktorat Jenderal Administrasi Hukum Umum (selanjutnya disebut Dirjen AHU) Kementerian Hukum dan Hak Asasi Manusia Republik Indonesia.

Setelah semua persyaratan tersebut terpenuhi, maka oleh BHP atas permohonan tersebut dibuatkan Berita Acara Pembukaan atas wasiat tertutup atau rahasia tersebut. Oleh BHP setelah dibuatkan Berita Acara selanjutnya ditandatangani dan diberi nomor oleh BHP untuk selanjutnya wasiat dikembalikan kepada ahli waris untuk dilaksanakan.

Namun, sistem pendaftaran yang demikian ternyata menimbulkan permasalahan hukum seperti misalnya ketika notaris membuat laporan terkait adanya suatu wasiat, ternyata surat keterangan tersebut tidak sampai kepada DPW atau dalam hal notaris lalai atau lupa untuk membuat laporan tetapi berdalih bahwa ia telah membuat dan mengirimkan laporan tersebut sementara pada kenyataannya notaris tidak membuat dan mengirimkan laporan. ${ }^{26}$ Berdasarkan permasalahan hukum yang 
ada di lapangan dan seiring perkembangan teknologi informasi saat ini, menuntut seluruh masyarakat pengguna layanan publik terutama jasa hukum agar dapat dilakukan melalui mekanisme online sistem serta dalam rangka untuk mewujudkan efisiensi dalam sistem pendaftaran wasiat tersebut, maka pada tanggal 28 Maret 2014, Kemenkum HAM RI melakukan launching sistem pendaftaran wasiat secara online oleh notaris.

Terkait pendaftaran wasiat, terdapat beberapa ketentuan Peraturan PerundangUndangan yang mengatur, antara lain yaitu Ordonansi Daftar Pusat Wasiat (ordonnantie op het Centraal Testarnentenregister) S. 1920305 jo. 1921-568 (mb. 1 Januari 1922) (Ord. 15 April 1920), Burgerlijk Wetboek, UndangUndang Nomor 2 Tahun 2014 Tentang Perubahan Atas Undang-Undang Nomor 30 Tahun 2004 Tentang Jabatan Notaris, dan Pasal 41-42 OV. Namun terkait mekanisme pendaftaran wasiat secara online, secara khusus telah diatur dalam Permenkumham No. 60/2016.

Berdasarkan Pasal 1 angka 6 Permenkumham No. 60/2016, Surat Keterangan Wasiat didefinisikan sebagai surat yang isinya menerangkan terdaftar atau tidak terdaftarnya akta wasiat yang dibuat di hadapan Notaris yang telah dilaporkan pada DPW. Sebagaimana diuraikan pada Pasal 17 Permenkumham No. 60/2016 tersebut, Surat Keterangan Wasiat tersebut dapat berupa keterangan mengenai terdaftar atau tidak terdaftarnya akta wasiat atas nama orang yang dimohonkan keterangan wasiatnya. Adapun hal-hal yang dimuat dalam laporan wasiat terdaftar tersebut adalah sebagai berikut:

a. Nomor dan tanggal akta wasiat;

b. Jenis wasiat (misal : wasiat umum, hibah wasiat, pencabutan wasiat, wasiat olografis dan lain-lain);

c. Nama pembuat wasiat dan nama dahulu (nama kecil) bila ada;

d. Tempat dan tanggal lahir serta alamat pembuat wasiat;

e. Nama notaris dan kedudukannya serta alamat lengkap notaris;

f. Nomor reportorium.

Upaya yang dilakukan oleh Dirjen AHU dengan memberikan kemudahan kepada masyarakat terkait dengan pendaftaran wasiat secara online memberikan manfaat yang luar biasa terutama terkait dengan kepastian terdaftarnya wasiat yang dibuat oleh si pewasiat di hadapan notaris, karena dengan menggunakan layanan online semua layanan jasa hukum dapat dilakukan dengan mudah, cepat dan biaya ringan serta jauh dari kesan adanya upaya pungutan liar atau pungli. Selain itu adanya ketentuan mengenai pendaftaran wasiat secara online ini tidak lain adalah untuk memberikan kemudahan bagi notaris yang dalam hal ini berkewajiban untuk mengirimkan laporan berkenaan dengan telah dibuatnya suatu wasiat ke pusat daftar wasiat pada kementerian yang menyelenggarakan sebagaimana diatur dalam Pasal 16 ayat (1) huruf j UUJN. 
Dengan adanya ketentuan pendaftaran wasiat online sebagaimana yang diatur dalam Permenkumham No. 60/2016, maka notaris tidak lagi mengirimkan data fisik secara manual sebagai bukti laporan terkait adanya suatu wasiat yang telah dibuat. Notaris hanya perlu melakukan registrasi untuk dapat masuk ke dalam website Dirjen AHU dan mengirimkan laporan terkait akta wasiat secara online.

Kelebihan pendaftaran wasiat secara online dengan menggunakan teknologi informasi, kepastian hukum akan terdaftarnya wasiat lebih besar karena dengan melakukan pendaftaran wasiat secara online, seketika itu juga akta wasiat yang dikirim melalui online sudah langsung ter-update atau dengan kata lain langsung masuk ke dalam data base Dirjen AHU online sehingga sangat kecil kemungkinan akta wasiat tersebut tidak terdaftar pada DPW. Hal ini sangat berbeda apabila dibandingkan dengan pendaftaran yang dilakukan secara manual dimana akan memakan waktu yang cukup lama dan terdapat kekhawatiran pendaftaran wasiat tersebut tidak sampai pada DPW karena terkendala dengan pengiriman, jangkauan wilayah dan lain sebagainya yang dapat mengakibatkan tidak terdaftarnya wasiat pada DPW.

Menurut Nurhendro Putranto, dengan adanya ketentuan online ini maka peran BHP menjadi tidak ada dalam hal berkenaan dengan pendaftaran wasiat. Setelah adanya ketentuan tersebut, BHP hanya berperan pada saat dilakukannya pedaftaran wasiat yang telah terbuka.Namun, adanya ketentuan pendaftaran wasiat secara online tersebut ternyata tidak benar-benar dimanfaatkan oleh sebagian notaris karena pada praktik di lapangan ternyata masih banyak notaris yang tidak mengirimkan daftar akta yang terkait dengan wasiat. ${ }^{27}$

Apabila pada bulan yang berkaitan pada suatu kantor notaris tidak ada dibuat suatu akta wasiat, maka tidak akan menimbulkan masalah apabila notaris tersebut tidak mengirimkan laporan mengenai pembuatan wasiat. Akan menjadi masalah apabila ternyata telah dibuat suatu akta wasiat, namun oleh notaris tidak dikirimkan daftar akta tersebut. Dalam Bab XI mengenai ketentuan sanksi dalam Pasal 84 Undang-Undang Nomor 30 Tahun 2004 tentang Jabatan Notaris, dikatakan bahwa apabila notaris melakukan tindakan pelanggaran terhadap ketentuan yang dimaksud dalam Pasal 16 ayat (1) huruf i maka mengakibatkan degradasi kekuatan pembuktian akta notaris ${ }^{28}$ suatu akta hanya mempunyai kekuatan pembuktian sebagai akta di bawah tangan atau suatu akta tersebut menjadi batal demi hukum sehingga dapat menjadi alasan bagi pihak yang menderita kerugian untuk menuntut penggantian biaya, ganti rugi, dan bunga kepada notaris. Namun

27 Wawancara dengan Ketua Balai Harta Peninggalan Surabaya, Sidoarjo, 15 Maret 2016.

28 Eko Hariyanti, dkk., "Pembatalan Akta Hibah Wasiat yang Dibuat di Hadapan Notaris dan Akibat Hukumnya", Jurnal Repertorium Edisi 3, ISSN:2355-2646, (Januari-Juni 2015): 184, diakses 16 April 2017, http://jurnal. hukum.uns.ac.id/index.php/repertorium/article/view/654/612. 
berdasarkan Pasal I angka 42 UUJN, maka ketentuan Bab XI tersebut dihapus dan dalam UUJN tidak memuat lagi ketentuan mengenai akibat hukum dari wasiat yang aktanya tidak dilaporkan oleh notaris. Pada Pasal 16 ayat (11) dan ayat (12) UUJN hanya menegaskan mengenai sanksi yang dapat dikenakan kepada notaris yang melanggar ketentuan Pasal 16 ayat (1) huruf $\mathrm{j}$ tersebut yang mana dalam ketentuan Pasal 91A UUJN dinyatakan bahwa ketentuan mengenai tata cara penjatuhan sanksi sebagaimana dimaksud dalam Pasal 16 ayat (11) diatur dalam Peraturan Menteri.

Dari uraian di atas, dapat ditarik suatu kesimpulan yaitu wasiat yang tidak didaftarkan pada DPW Subdirektorat Harta Peninggalan baik sebelum maupun sesudah sistem online kedudukan hukum aktanya tetap sebagai akta otentik dimana pendaftaran secara online ini hanya sebagai bentuk tertib administratif saja dan dapat dijadikan sebagai alasan bagi pihak yang terkait untuk berupaya membatalkan wasiat tersebut, karena kewajiban mengenai pendaftaran tersebut telah diatur dalam Peraturan Perundang-Undangan sehingga apabila ketentuan tersebut dilanggar konsekuensi hukumnya adalah wasiat tersebut dapat dijadikan dasar gugatan oleh para ahli waris.

Sedangkan apabila notaris melakukan pendaftaran lewat dari 5 (lima) hari pada minggu pertama pada setiap bulan berikutnya seperti yang dimaksud dalam Pasal 16 ayat
(1) huruf j UUJN, maka akses pendaftaran tersebut akan terkunci. Yang dimaksud dengan terkunci di sini ialah notaris tidak dapat lagi melakukan pelaporan wasiat secara online pada bulan tersebut sehingga redaksi laporan bulanan yang disampaikan ke DPW adalah nihil sedangkan apabila notaris yang bersangkutan membuat laporan akta wasiat, maka redaksi laporan yang disampaikan ke DPW adalah terdaftar.

Sebagaimana yang dimaksud pada Pasal 91A, tata cara penjatuhan sanksi bagi notaris diatur dalam suatu Peraturan Menteri yang mana sampai saat ini peraturan yang dimaksud masih dalam tahap penyusunan. Diharapkan pada peraturan tersebut akan dimuat secara jelas mengenai akibat hukum dari wasiat yang tidak didaftarkan secara online pada Kementerian Hukum dan HAM RI. Dengan adanya aturan tegas mengenai hal tersebut, diharapkan pula para notaris menjadi lebih tertib dalam hal pengiriman laporan sebagaimana yang ditegaskan pada Pasal 16 ayat (1) huruf j UUJN.

Untuk itu, pada Peraturan Menteri yang masih dalam tahap penyusunan tersebut, diharapkan pula agar mengatur mengenai sanksi dan tata cara penjatuhannya secara jelas. Dan pada praktiknya, diharapkan agar sanksi tersebut adil bagi para pihak dan diterapkan tanpa pandang bulu terhadap semua notaris sehingga memberikan efek jera dan notaris akan menjadi lebih tertib. 


\section{B. Tanggung Gugat Notaris Yang Tidak Mendaftarkan Wasiat Secara Online pada Kementerian Hukum dan Hak Asasi Manusia Republik Indonesia}

Berbicara mengenai tanggung gugat tidak terlepas dari sanksi yang akan diberlakukan pada notaris. Bila ditelisik lebih dalam lagi, selain sanksi administratif sebagaimana yang telah dibahas di subbab sebelumnya, ternyata ada sanksi lain bagi notaris. Ketentuan mengenai sanksi tersebut diatur dalam Pasal 16 ayat (12) UUJN yang menyatakan bahwa selain dikenai sanksi sebagaimana dimaksud pada ayat (11), pelanggaran terhadap ketentuan Pasal 16 ayat (1) huruf j dapat menjadi alasan bagi pihak yang menderita kerugian untuk menuntut penggantian biaya, ganti rugi, dan bunga kepada notaris. Dalam konteks ini mengapa yang digunakan istilah tanggung gugat adalah karena sanksi tersebut di atas menekankan pada adanya kerugian bagi suatu pihak sehingga akan lebih tepat bila digunakan istilah tanggung gugat.

Sebagaimana yang telah diuraikan sebelumnya, notaris berkewajiban untuk mengirimkan laporan mengenai adanya suatu wasiat yang telah dibuat di hadapannya. Yang menjadi poin masalah dalam hal ini adalah ketika notaris tidak mengirimkan laporan sebagaimana yang dimaksud. Dalam hal ini dapat dikatakan bahwa notaris telah melanggar kewajibannya sebagaimana yang dimaksud dalam Pasal 16 ayat (1) huruf $\mathrm{j}$ dan itu merupakan suatu kesalahan dan dapat dikategorikan sebagai perbuatan melanggar hukum (onrechtmatigedaad).

Bentuk tanggung gugat yang dianut oleh Pasal 1365 BW ini adalah tanggung gugat berdasarkan kerugian (liability based fault). Hal ini dapat dilihat dalam ketentuan pasal tersebut yang mensyaratkan adanya kesalahan pada pelaku untuk sampai pada keputusan apakah perbuatan seseorang itu merupakan perbuatan melanggar hukum. Terdapat empat kriteria perbuatan melanggar hukum, keempat kriteria tersebut adalah:

a. Bertentangan dengan kewajiban hukum si pelaku;

b. Melanggar hak subjektif orang lain;

c. Melanggar kaidah tata susila;

d. Bertentangan dengan asas kepatutan, ketelitian serta sikap hati-hati yang seharusnya dimiliki seseorang dalam pergaulan dengan sesama warga masyarakat atau terhadap harta benda orang lain. ${ }^{29}$

Untuk mengetahui apakah notaris dalam konteks kasus ini benar melakukan suatu perbuatan melanggar hukum atau tidak, maka terlebih dahulu akan diuraikan unsur-unsur dari Pasal 1365 BW yang mengatur mengenai perbuatan melanggar hukum. Pasal 1365 BW menyatakan bahwa tiap perbuatan melanggar hukum yang membawa kerugian kepada orang lain, mewajibkan orang yang karena salahnya

29 Sjaifurrachman, Aspek Pertanggungjawaban Notaris dalam Pembuatan Akta, (Surabaya: Mandar Maju, 2011), hlm. 179 
menerbitkan kerugian itu, mengganti kerugian tersebut. Unsur-unsur dari Pasal 1365 BW meliputi:
a. Adanya perbuatan;
b. Adanya kesalahan;
c. Adanya kerugian;
d. Adanya hubungan sebab akibat atau kausalitas.

Adanya perbuatan sebagai salah satu unsur dari Pasal 1365 BW yang dimaksud adalah seseorang telah melakukan suatu tindakan atau perbuatan. Tindakan atau perbuatan tersebut dapat berupa aktivitas tertentu maupun suatu pasivitas yaitu tidak melakukan perbuatan sama sekali atau diam. Suatu tindakan yang sifatnya pasif ini tidak lain adalah tidak melaksanakan sesuatu yang seharusnya menjadi suatu kewajiban dari seseorang untuk dilaksanakan. ${ }^{30}$ Dalam hal ini notaris yang tidak mengirimkan laporan mengenai akta wasiat tentunya telah melakukan suatu perbuatan yang pasif dengan tidak melakukan kewajibannya tersebut ${ }^{31}$. Atas dasar tersebut, maka unsur adanya suatu perbuatan dalam Pasal 1365 BW telah terpenuhi.

Adanya kesalahan sebagai salah satu unsur yang dimaksud dalam Pasal 1365 BW adalah bahwa perbuatan yang dilakukan oleh seseorang merupakan perbuatan yang bertentangan dengan undang-undang atau bertentangan dengan ketertiban umum, kesusilaan, atau asas kehati-hatian dan asas kepatuhan yang berlaku dalam kehidupan masyarakat, maka perbuatan tersebut merupakan bentuk kesalahan. ${ }^{32}$ Dalam hal ini dikaitkan dengan perbuatan notaris yang tidak mengirimkan laporan mengenai wasiat secara online sebagaimana yang telah menjadi kewajibannya dan diatur dalam Pasal 16 ayat (1) huruf j UUJN, maka tindakan notaris tersebut jelas merupakan suatu kesalahan karena terbukti melanggar ketentuan Pasal 16 ayat (1) huruf j UUJN.

Adanya kerugian sebagai salah satu unsur dari Pasal 1365 BW yang dimaksud adalah bahwa berkurangnya nilai suatu barang baik sebagian maupun keseluruhan sehingga mengurangi kepuasan seseorang. ${ }^{33}$ Terkait dengan notaris yang tidak melaksanakan kewajibannya untuk mendaftarkan suatu wasiat, hal tersebut dapat mengakibatkan para ahli waris tidak mengetahui adanya suatu wasiat tersebut dan dapat menimbulkan kerugian bagi mereka. Kerugian yang dimaksud dalam ketentuan Pasal 1365 BW dapat dibedakan dalam 2 (dua) macam, yaitu kerugian yang bersifat materiil dan kerugian yang bersifat immaterial. Kerugian yang

30 Yulaika Ningsih, "Tanggung Gugat dan Tanggung Jawab Notaris Karena Kesalahan Penulisan Luas Tanah Dalam Akta Jual Beli”, Tesis Program Studi Magister Kenotariatan, (Surabaya: Universitas Airlangga, 2005), Tidak Dipublikasikan, hlm. 17.

31 Debora Claudia Panjaitan, "Pembatalan Akta Wasiat sebagai Akibat Perbuatan Melawan Hukum yang Dilakukan Notaris (Studi Kasus Putusan MA No. 3124 K/PDT/2013 Antara Penggugat DM vs Tergugat Notaris LSN)", Premise Law Jurnal, Vol. 21, (2016): 9, diakses 17 April 2017, http://jurnal.usu.ac.id/index. php/premise/article/view/16890/7133.

32 Ibid., hlm. 17-18.

33 Ibid. 
bersifat materiil adalah kerugian yang dapat dinilai dengan uang dan berkaitan dengan harta kekayaan. Kerugian yang bersifat materiil pada umumnya meliputi kerugian yang diderita oleh si penderita dari keuntungan yang seharusnya dapat diperoleh. ${ }^{34}$ Sedangkan kerugian yang bersifat immaterial adalah kerugian yang berhubungan dengan moril yang pada umumnya sulit dinilai dengan uang. Kerugian yang bersifat immaterial ini dengan berkurangnya kesenangan hidup yang semestinya dapat dinikmati oleh seseorang, misalnya kematian, cacat tubuh seumur hidup, luka-luka, dan sebagainya. Dalam menetukan besarnya ganti rugi harus diperhitungkan keuntungan yang akan diperoleh pihak yang mengalami kerugian sebagai akibat dari perbuatan melanggar hukum. ${ }^{35}$ Dalam hal ini, dilihat dari kedudukan hukum akta wasiat yang tetap sebagai akta otentik yang sah, maka bentuk kerugian yang ada lebih kepada kerugian dalam bentuk immaterial karena wasiat tersebut pada dasarnya masih dapat tetap dilaksanakan sebagaimana mestinya, hanya saja prosedur administratifnya tidak terpenuhi.

Adanya hubungan sebab akibat atau kausalitas yang dimaksud dalam Pasal 1365 BW adalah bahwa suatu akibat tertentu tentu ada yang menyebabkannya. ${ }^{36}$ Dalam hal ini kerugian yang timbul pada ahli waris merupakan suatu akibat dari tindakan notaris yang tidak melakukan kewajibannya sebagaimana diatur dalam Pasal 16 ayat (1) huruf $\mathrm{j}$ UUJN untuk mengirimkan daftar laporan mengenai wasiat. Karena wasiat tersebut tidak didaftarkan, hal tersebut membuat asas publisitas tidak terpenuhi sehingga pihak ketiga yang dalam hal ini adalah ahli waris, menjadi tidak mengetahui akan adanya suatu wasiat yang ditujukan kepada mereka.

Dengan memperhatikan uraian dari unsurunsur Pasal 1365 BW tentang perbuatan melanggar hukum yang mana di dalamnya ada unsur perbuatan, kesalahan, kerugian dan hubungan kausalitas, maka tindakan notaris yang tidak mendaftarkan wasiat secara online dengan sendirinya telah memenuhi unsurunsur tersebut sehingga dapat dikatakan bahwa apa yang telah dilakukan oleh notaris adalah suatu perbuatan yang melanggar hukum.

Sedangkan, berdasarkan kriteria perbuatan melanggar hukum yang telah disebutkan di atas, maka perbuatan notaris yang dimaksud dalam hal ini dapat dimasukkan dalam kriteria bertentangan dengan kewajiban hukum si pelaku. Kewajiban hukum bagi notaris sebagaimana tercantum dalam Pasal 16 ayat (1) huruf j UUJN dimana ketentuan ini mewajibkan notaris untuk mengirimkan daftar akta sebagaimana dimaksud dalam huruf $i$ atau daftar nihil yang berkenaan dengan wasiat 
pada Kementerian yang menyelenggarakan urusan pemerintahan di bidang hukum dalam waktu 5 (lima) hari pada minggu pertama setiap bulan berikutnya tidak dilaksanakan sebagaimana mestinya sehingga menimbulkan akibat yaitu adanya kerugian bagi para ahli waris. Tindakan notaris tersebut bertentangan dengan kewajibannya yang telah diatur dalam undang-undang sehingga dapat dimasukkan dalam kriteria ini. Untuk itu, apabila timbul kerugian dari perbuatan notaris tersebut, maka notaris telah melakukan perbuatan melanggar hukum.

Berdasarkan uraian di atas, dapat dikatakan bahwa tindakan notaris yang melanggar ketentuan Pasal 16 ayat (1) huruf j UUJN adalah perbuatan melanggar hukum dalam kriteria bertentangan dengan kewajiban hukum si pelaku dan atas dasar tindakan tersebut ada pihak yang menderita kerugian, dimana yang dimaksud dengan pihak yang menderita kerugian dalam hal ini adalah para ahli waris. Para ahli waris tersebut dengan alasan menderita kerugian dapat menuntut ganti rugi kepada notaris yang bersangkutan sebagai bentuk tanggung gugat notaris yang tidak mendaftarkan wasiat secara online sebagaimana yang dimuat dalam ketentuan Pasal 16 ayat (12) UUJN.

\section{Simpulan}

1. Dapat dikatakan bahwa kedudukan akta wasiat yang tidak didaftarkan secara online pada Kementerian Hukum dan HAM adalah tetap sebagai akta otentik dan tidak memiliki akibat hukum yang dapat membatalkan akta tersebut, hanya saja akta tersebut tidak memenuhi asas publisitas yang dapat membuat pihak ketiga atau ahli waris dianggap tidak mengetahui adanya suatu wasiat yang ditujukan bagi mereka. Terhadap notaris yang tidak memenuhi kewajibannya sebagaimana yang dimaksud dalam Pasal 16 ayat (1) huruf j UndangUndang Nomor 2 Tahun 2014 Tentang Perubahan Atas Undang-Undang Nomor 30 Tahun 2004 Tentang Jabatan Notaris (selanjutnya disebut UUJN), maka terhadap notaris tersebut dapat dijatuhi sanksi administratif yang ditegaskan ketentuannya pada Pasal 16 ayat (11) UUJN. Menurut Pasal 91A UUJN ketentuan mengenai tata cara penjatuhan sanksi sebagaimana dimaksud dalam Pasal 16 ayat (11) UUJN tersebut diatur dalam Peraturan Menteri. Sedangkan pada Pasal 84 Undang-Undang Nomor 30 Tahun 2004 Tentang Jabatan Notaris yang saat ini sudah tidak diberlakukan lagi, diatur mengenai akibat hukum dari akta wasiat yang tidak didaftarkan pada Kementerian Hukum dan HAM, yang menyatakan bahwa akta tersebut akan terdegradasi menjadi akta bawah tangan dan dapat batal demi hukum, yang dalam hal ini notaris tidak memenuhi ketentuan Pasal 16 ayat (1) huruf i Undang-Undang Nomor 30 Tahun 2004 Tentang Jabatan Notaris. 
2. Atas tindakan notaris yang tidak memenuhi ketentuan Pasal 16 ayat (1) huruf $\mathrm{j}$ UUJN dan menimbulkan kerugian bagi ahli waris, maka ahli waris dapat menggugat notaris atas dasar perbuatan melanggar hukum dimana notaris yang bersangkutan tidak memenuhi kewajiban hukumnya sebagaimana yang dimaksud pada Pasal 16 ayat (1) huruf j UUJN. Atas kerugian yang diderita oleh ahli waris tersebut, berdasarkan UUJN maka notaris dapat dituntut penggantian biaya, ganti rugi dan bunga sebagaimana yang ditegaskan dalam Pasal 16 ayat (12) UUJN.

\section{DAFTAR PUSTAKA}

\section{Buku}

Afandi, Ali. Hukum Waris, Hukum Keluarga, Hukum Pembuktian. Cetakan Ke-empat.

Jakarta: Rineka Cipta, 2000.

Ali, Zainuddin. Pelaksanaan Hukum Waris di Indonesia. Jakarta: Sinar Grafika 2010.

Asri, Benyamin dan Thabrani Asri. Dasar-

Dasar Hukum Waris Barat (Suatu

Pembahasan Teoritis dan Praktik.).

Bandung: Tarsito, 1988.

Kie, Tan Thong. Studi Notariat dan Serba-

Serbi Praktek Notaris. Jakarta: Ichtiar Baru Van Hoeve, 2007.

Marzuki, Peter Mahmud. Penelitian Hukum.

Jakarta: Kencana, 2005.

Oemarsalim, Dasar-Dasar Hukum Waris di

Indonesia. Jakarta: Rineka Cipta, 2012.

Prawirohamidjojo, R., Soetojo. Hukum

Waris Kodifikasi. Surabaya: Airlangga

University Press, 2000.

Setiawan, Wawan. Tanggung Jawab Notaris dalam Pembuatan Akta. Semarang: Makalah dalam Seminar Nasional

Sehari Ikatan Mahasiswa Notariat Universitas Diponegoro, 1991.
Sjaifurrachman. Aspek Pertanggungjawaban Notaris dalam Pembuatan Akta. Surabaya: Mandar Maju, 2011.

Subekti, R. Pokok-Pokok Hukum Perdata. Cetakan XXXII. Jakarta: Intermasa, 2005 .

Suparman, Eman. Hukum Waris Indonesia Dalam Perspektif Islam, Adat, dan BW. Bandung: Refika Aditama, 2013.

Suparman, Maman. Hukum Waris Perdata. Jakarta: Sinar Grafika, 2015.

\section{Jurnal}

Hariyanti, Eko, dkk. "Pembatalan Akta Hibah Wasiat yang Dibuat di Hadapan Notaris dan Akibat Hukumnya". Jurnal Repertorium Edisi 3, ISSN: 2355-2646, (Januari-Juni 2015): 184. Diakses 16 April 2017. http://jurnal.hukum.uns. ac.id/index.php/repertorium/article/ view/654/612.

Panjaitan, Debora Claudia. "Pembatalan Akta Wasiat sebagai Akibat Perbuatan Melawan Hukum yang Dilakukan Notaris (Studi Kasus Putusan MA No. 
3124 K/PDT/2013 Antara Penggugat

DM vs Tergugat Notaris LSN)". Premise Law Jurnal, Vol. 21, (2016):

9. Diakses 17 April 2017. http://jurnal. usu.ac.id/index.php/premise/article/ view/16890/7133.

\section{Tesis}

Dewi, Sofa. "Tanggung Gugat Notaris Sebagai Pejabat Umum". Tesis Program Magister Kenotariatan. Surabaya: UNAIR, 2002. Tidak Dipublikasikan.

Ningsih, Yulaika. "Tanggung Gugat dan Tanggung Jawab Notaris Karena Kesalahan Penulisan Luas Tanah Dalam Akta Jual Beli”. Tesis Program Studi Magister Kenotariatan. Surabaya: Universitas Airlangga, 2005. Tidak Dipublikasikan.

Prastuti, Mireille Titisari Miart. "Peran dan Tanggung Jawab Notaris Atas Akta Wasiat (Testament Acte) yang Dibuat di Hadapannya". Tesis Program Magister Kenotariatan. Semarang: UNDIP, 2006. Diakses 10 Desember 2016. http://eprints.undip.ac.id/15710/1/M. Titisari_Miarti_Prastuti.pdf.

\section{Peraturan Perundang-undangan}

Undang-Undang Dasar Negara Republik Indonesia Tahun 1945.

Burgerlijk Wetbook Staatsblaad Nomor 23 Tahun 1847 (Staatsblad 1847 Nomor 23).

Undang-undang Nomor 2 Tahun 2014 tentang Perubahan Atas Undang-Undang Nomor 30 Tahun 2004 Tentang Jabatan Notaris.

Peraturan Menteri Hukum dan Hak Asasi Manusia RI Nomor M-01.PR.07.10 Tahun 2005 tentang Organisasi dan Tata Kerja Kantor Wilayah Departemen Hukum dan Hak Asasi Manusia Republik Indonesia.

Keputusan Menteri Agama Republik Indonesia Nomor 154 Tahun 1991 tentang Pelaksanaan Instruksi Presiden Republik Indonesia Nomor 1 Tahun 1991 tentang Kompilasi Hukum Islam.

Keputusan Menteri Kehakiman RI Nomor M.06-PR.07.01 Tahun 1987 tentang Penghapusan Perwakilan Balai Harta Peninggalan di Seluruh Indonesia. 